\title{
ASCARIS LUMBRICOIDES: EPIDEMIOLOGY, DIAGNOSIS, TREATMENT, AND CONTROL
}

\author{
KANAAN AL-TAMEEMI ${ }^{1}$, RAIAAN KABAKLI ${ }^{2 *}$
}

${ }^{1}$ Department of Microbiology, Faculty of Pharmacy, Al Andalus University for Medical Sciences, Tartous, Syria. ${ }^{2}$ Department of Basic Sciences, Faculty of Pharmacy, Al Andalus University for Medical Sciences, Tartous, Syria. Email: raiaan.youssef@gmail.com

Received: 24 January 2019, Revised and Accepted: 28 February 2020

ABSTRACT

Although Ascaris lumbricoides is a common intestinal parasite of humans with worldwide distribution causing ascariasis, Ascaris is a neglected disease and still is a burden in developing countries. Furthermore, the parasite's permanence and prevalence present difficulties in control strategies. Therefore, more research on the mechanisms of resistance to infection is required for reducing prevalence parasite and control of infections.

Keywords: Ascaris lumbricoides, Ascariasis, Intestinal obstruction, The prevalence.

(c) 2020 The Authors. Published by Innovare Academic Sciences Pvt Ltd. This is an open access article under the CC BY license (http://creativecommons. org/licenses/by/4. 0/) DOI: http://dx.doi.org/10.22159/ajpcr.2020.v13i4.36930

\section{INTRODUCTION}

A. lumbricoides is one of the most common intestinal helminthic human parasites, infecting 1.2 billion people worldwide [1]. This is due to the fertilization ability of female worms to produce large numbers of eggs that are characterized by being highly resistant to environmental conditions, as well as to the ease of infection transmission among people due to the ingestion of eggs containing the larvae in its second stage with food and water that are contaminated with them. There is no immunity when reinfection occurs [2]. Acute Ascaris infections cause about 60,000 deaths per year, mainly in children due to intestinal obstruction [3]. An infection occurs to both male and female, but children are more susceptible to infection than adults, especially between the ages of 3 and 8 years $[3,4]$. This is mainly distributed in areas with warm, moist climates. Ascariasis is prevalent in at least 150 countries around the world. The distribution of ascariasis shows that $8.3 \%$ of cases were in South America, Central America, and the Caribbean, and $16.7 \%$ of cases were in Africa and the Middle East, and $75 \%$ of cases were in Central and Southeast Asia and the Oceanic region [5].

More advances happened over the past century in reducing the prevalence of parasitic infection in many regions, but regrettably, these infections remain part of the daily life of impoverished populations living in the tropical and subtropical regions where sanitation and hygiene are poor [6].

\section{LIFE CYCLE AND PATHOLOGY}

Transmission of Ascaris eggs is associated with accidental contact with soil [7] or ingestion of contaminated vegetables, greens, and fruits $[3,8]$. The infection may also occur in those regions where human feces are used as a fertilizer for growing vegetables [9].

Soils may contain unfertilized eggs (not infective) Fig. 1a and fertilized eggs Fig. $1 b$ which cause the infection. Hatching of the eggs does not happen in the soil but occurs in the intestines of hosts. The eggs in the soil remain viable and capable of infection for a period of up to 10 years. They are also resistant to the usual ways of chemical water purification $[9,10]$.

Adult worms are creamy-white organisms with a pinkish color. Male worms measure $15-31 \mathrm{~cm}$ in length and have posterior end curved ventrally, Fig. 2b. Female worms are larger, $20-49 \mathrm{~cm}$ in length, Fig. 2a. The fertilized egg contains a second-stage larva that measures 50-70×40-50 $\mu \mathrm{m}$ (infective stage).
The eggs hatch in the jejunum into larvae within a few hours of ingestion, Fig. 3 . The larvae pass the intestinal mucosa and migrate through the lymphatic system into the portal vein to the liver in 2-8 days. They move through the heart to the lungs. They penetrate the capillary walls and enter the lung alveoli where they measure $564 \times 28 \mu \mathrm{m}$. They stay about 10 days in the lungs when they molt twice before reaching the fourth-stage larvae and grow to $1700-2000 \mu \mathrm{m}$ in size. Then, they get back to the trachea and the pharynx.

The larvae pass the esophagus and through the stomach to the small intestine. When they arrive at the small intestine, they molt and then become immature adults (Fig. 4). These worms develop into adult males and females in 14-20 days after mating. The female releases millions of eggs into the feces after about 70 days of ingestion of infective eggs. The shell of eggs gives the ability to resist to various environmental conditions and can remain in the soil for up to 6 years [1,3,5,10-13]. They can be carried by the wind in dry dust and contaminate new human regions, Fig. 2. In general, the eggshell consists of three basic layers $[14,15]$ :

- Lipoidal inner layer: It regulates the temperature for larvae

- Chitinous middle layer: It protects larvae from differentenvironmental conditions

- The outer layer of protein: It gives eggs the ability to adhere to other objects.

\section{SYMPTOMS}

The first stages of infection are asymptomatic, especially when the number of present worms in the samples is tenuous [1]. Moderate and

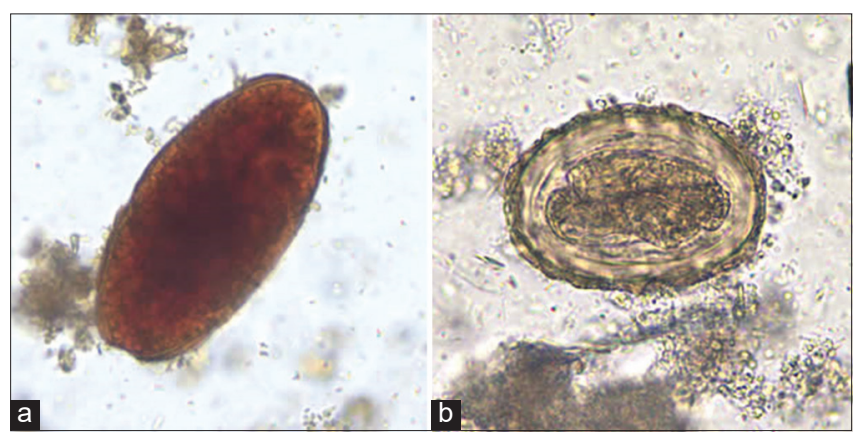

Fig. 1: (a) Unfertilized egg of Ascaris lumbricoides, (b) fertilized egg of $A$. lumbricoides [6] 

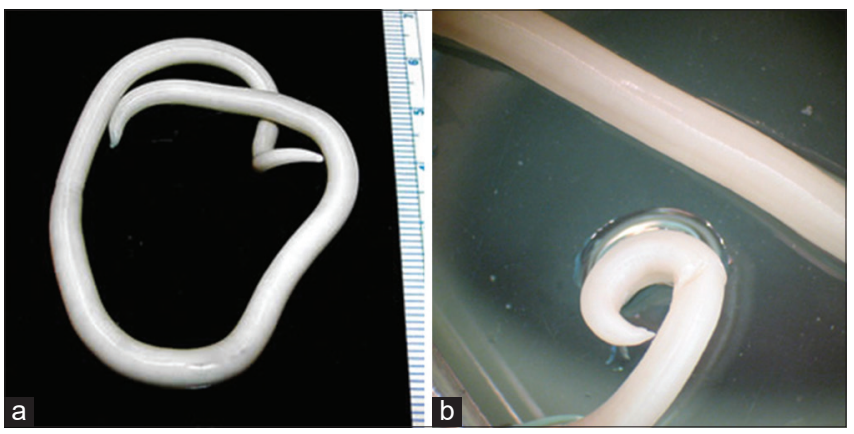

Fig. 2: (a) Adult female Ascaris lumbricoides, (b) posterior end of a male $A$. lumbricoides, showing the curled tail [6]

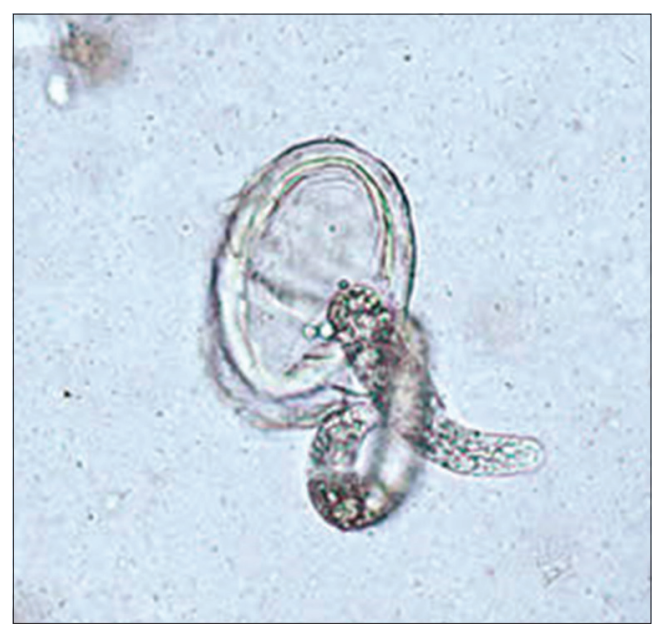

Fig. 3: Larva of Ascaris lumbricoides hatching from an egg [6] chronic infections cause various symptoms, depending on which part of the body is affected. For example, in the lungs, the migrating larvae cause cough, fever, and skin rashes for a few days [2,16-18]. When the larvae move from the blood in capillaries into the lung alveoli result in hemorrhage and the alveolar sacs become filled with serous exudate.

A large number of adult worms presented in the intestines cause mechanical obstruction of the bowel and bile and pancreatic ducts, Fig. 5, vomiting, and abdominal pain. Worms migration leads to bowel perforation and peritonitis. In some cases, the adult worms passing from anal or mouth $[16,19]$ cause diarrhea or bloody stools, nutrient malabsorption that happens by Ascaris secreting a number of digestive enzymes such as amylase, protease, and lipase into the intestinal canal $[20,21]$. Worms may invade the bile ducts, the liver, pancreatic duct, surgical wounds, and the peritoneum causing abscesses $[3,22]$.

\section{DIAGNOSIS}

A. lumbricoides can be diagnosed by the following methods: $[7,12,24]$

1. Seeing the worms in the intestines through endoscopy $[17,25]$, sonographic images [26], X-ray photographs, and tomographic images [27-33]

2. Seeing worms after they are expelled naturally

3. Detecting the worms' metabolites in urine such as 2-methylbutyramide and 2-methyl-valeramide [34]

4. Seeing the worms' eggs and larvae in feces under a microscope (Kato-Katz thick smear, FLOTAC, McMaster egg counting technique, Baermann). This way is the simplest and widely used in developing countries [30-36]

5. Serological diagnosis: Detection of antibodies could be a simpler, more rapid diagnosis of infection than conventional stool microscopy. Few studies have evaluated the use of this method, antibody titers have been associated with larval stage and may remain in high rates for several months, even after treatment, especially in regions where

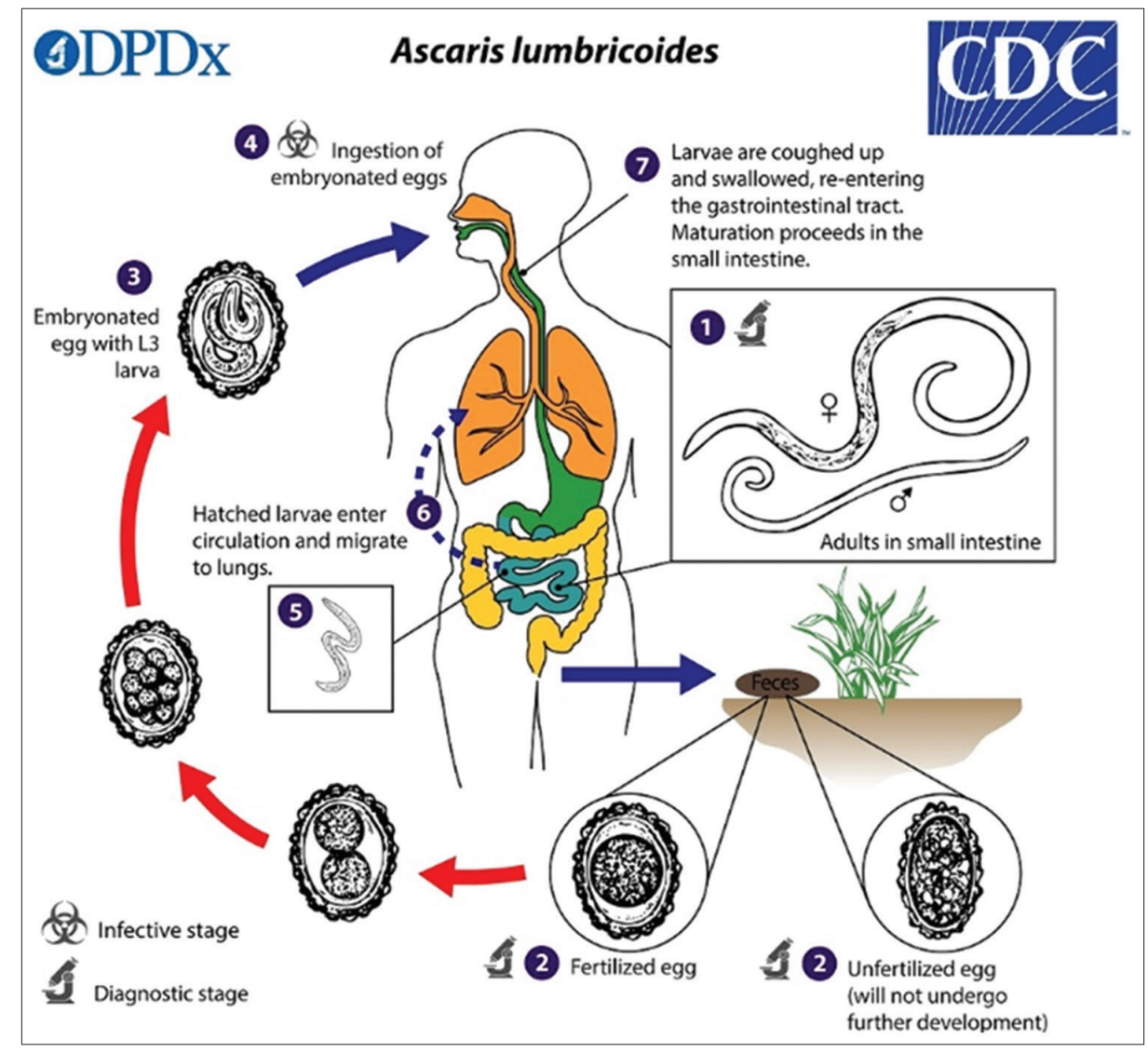

Fig. 4: Life cycle of Ascaris lumbricoides [6] 


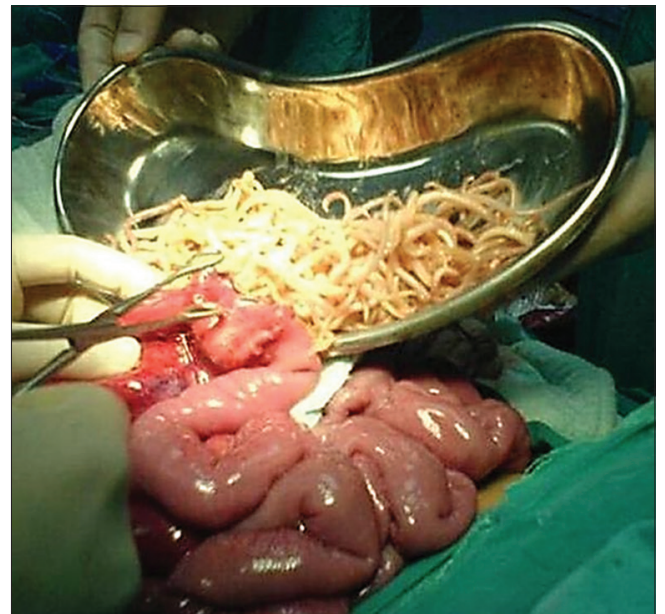

Fig. 5: Extraction of Ascaris lumbricoides from jejunum [23]

reinfection is continual [30,36-39]; therefore, this method is not suitable to detect active Ascaris infection and could not give a real number of patients in need of treatment [35].

\section{TREATMENT AND CONTROL}

The aim of the most control programs is to reduce the intensity of infection, thus there are strategies for Ascaris control, such as improvements in sanitation hygiene and health education and chemotherapy $[1,11,40,41]$. Early diagnosis of $A$. lumbricoides infection provides the choice of suitable and typical treatment for saving a patient's life [42].

The drugs recommended by the WHO for treatment are albendazole, mebendazole, levamisole, and pyrantel pamoate [11,43-45], and other drugs including piperazine and nitazoxanide. Albendazole is supplied in tablets of $200 \mathrm{mg}$ albendazole, it is used as two tablets or $20 \mathrm{ml}$ suspension to both adults and children above the age of 2 years. Mebendazole is used to kill the worms in the intestines then expels them within $24 \mathrm{~h}$ of drug administration. Mebendazole is available in oral tablets (100 $\mathrm{mg}$ ) and a suspension containing $20 \mathrm{mg}$ Mebendazole/ml $[3,7,46]$.

Vaccines were made from antibodies (predominantly immunoglobulin E) and the response is thought to be responsible for some immunity, but this way has proved none effective [47]. Future efforts may lead to the development of vaccines that will provide better control and management of the infection [3].

Certain local herbs, in some countries, are used as an alternative treatment of ascariasis. The plants include Prunus mume, Asarum heterotropoides, Zingiber officinale, Angelica sinensis, Phellodendron amurense, Panax ginseng, Cinnamomum cassia, and Zanthoxylum bungeanum [48-51]. Chenopodium ambrosioides is used as a herbal remedy in South and Central America [3].

\section{CONCLUSION}

Briefly, A. lumbricoides infection is a significant global health problem, especially in tropical and subtropical developing countries. Patients can be infected with abdominal pain symptoms and will continue to cause repeated complications throughout life.

Ascaris is an infectious and persistent parasite; its large size and its migratory pathway through the tissues enhance its danger on public health.

More awareness is very important to promote good hygiene and creative programs in the affected areas to disposal of fecal material and regular deworming.

\section{AUTHORS' CONTRIBUTIONS}

Both authors have contributed to the preparation of this review and editing of the manuscript.

\section{CONFLICTS OF INTEREST}

There are no conflicts of interest.

\section{AUTHORS' FUNDING}

No funding.

\section{REFERENCES}

1. Dold C, Holland CV. Ascaris and ascariasis. Microbes Infec 2011;13:632-7.

2. Shah J, Shahidullah A. Ascaris lumbricoides: A startling discovery during screening colonoscopy. Case Rep Gastroenterol 2018;12:224-9.

3. Scott ME. Ascaris lumbricoides: A review of its epidemiology and relationship to other infections. Ann Nestlé 2008;66:7-22.

4. Available from: https://www.who.int/water_sanitation_health/diseasesrisks/diseases/ascariasis/en/.

5. Asaolu SO, Ofoezie IE. Ascaris SPP. In: Global Water Pathogen Project. E. Lansing, MI: Michigan State University, UNESCO; 2018. p. 3-39. Available from: http://www.waterpathogens.org/book/ascaris. [Last accessed on 2018 Apr 12].

6. Available from: https://www.cdc.gov/dpdx/ascariasis/index.html. [Last accessed on 2019 Jul 19].

7. Wong MS, Bundy DA, Golden MH. The rate of ingestion of Ascaris lumbricoides and Trichuris trichiura eggs in soil and its relationship to infection in two children's homes in Jamaica. Trans R Soc Trop Med Hyg 1991;85:89-91.

8. Al-Tameemi K, Dayoub A, Mazloom M. Contamination of water with helminth eggs: A case study of Sourani dam Lake-Tartus governorate. Asian J Pharm Clin Res 2019;12:1-3.

9. Khuroo MS. Ascariasis. Gastroenterol Clin Med J 1996;25:553-77.

10. Kawoosa Z, Javid G, Yattoo GN, Gulzar GM, Sodhi JS, Shah AH, et al. To assess the efficacy and safety of various anti-heliminthics against Ascariasis lumbricoides among a study population in North India. OGH Rep 2018;7:25-34.

11. Asaolu SO, Ofoezie IE, Odumuyiwa PA, Sowemimo OA, Ogunniyi TA. Effect of water supply and sanitation on the prevalence and intensity of Ascaris lumbricoides among pre-school-age children in Ajebandele and Ifewara, Osun State, Nigeria. Trans R Soc Trop Med Hyg 2002;96:600-4.

12. Dold C, Holland CV. Ascaris and ascariasis, Microbes Infec 2010;10:S1286-4579.

13. Lima EO, Esteves CZ, Oliveira DN, Guerreiro TM, Melo CF, Catharino RR. In: Rodrigo L, editor. Mass Spectrometry and Metabolomics--New Approaches for Helminth Biochemical Studies in Human Helminthiasis. London, UK: In Tech Open Limited; 2017.

14. Rojas-Valencia MN. In: Méndez-Vilas A, editor. Research on Ozone Application as Disinfectant and Action Mechanisms on Wastewater Microorganisms, Science Against Microbial Pathogens: Communicating Current Research and Technological Advances. Badajoz, Spain: Formatex Research Center; 2011.

15. Lýsek H, Malínský J, Janisch R. Ultrastructure of eggs of Ascaris lumbricoides Linnaeus, 1758. I. Egg-shells. Folia Parasitol (Praha) 1985;32:381-4.

16. Coles GC. Allergy and immunopathology of ascariasis. In: Crompton DW, Nesheim MC, Pawlowski ZS, editors. Ascariasis and Its Public Health Significance. London: Taylor and Francis; 1985. p. 167-84.

17. Yamashita ET, Takahashi W, Kuwashima DY, Langoni TR, Costa-Genzini A. Diagnosis of Ascaris lumbricoides infection using capsule endoscopy. World J Gastrointest Endosc 2013;5:189-90.

18. Kanneganti K, Makker JS, Remy P. Ascaris lumbricoides: To expect the unexpected during a routine colonoscopy. Case Rep Med 2013;2013:579464.

19. Carroll KC, Hobden JA, Miller S, Morse SA, Mietzner TA, Detrick B, et al. Medical Microbiology. New York: McGraw-Hill Education; 2016.

20. Tripathy K, González F, Lotero H, Bolaños O. Effects of Ascaris infection on human nutrition. Am J Trop Med Hyg 1972;20:212-18.

21. Freij L, Meeuwisse GW, Berg NO, Wall S. Ascariasis and malnutrition. A study in urban Ethiopian children. Am J Clin Nutr 1979;32:1545-53.

22. Wani I, Maqbool M, Amin A, Shah F, Keema A, Singh J. et al. Appendiceal ascariasis in children. Ann Saudi Med 2010;30:63-6. 
23. Yetim I, Ozkan OV, Semerci E, Abanoz R. Rare cause of intestinal obstruction, Ascaris lumbricoides infestation: Two case reports. Cases J 2009;2:7970.

24. Holland C. Ascaris: The Neglected Parasite. Amsterdam: Elsevier Inc.; 2013.

25. Somani P, Sharma M, Jindal S. Endoscopic ultrasound appearance of dead Ascaris lumbricoides in the biliary tract. Endoscopy 2017;49:E275-6.

26. $\mathrm{Wu} \mathrm{S}$. Sonographic findings of Ascaris lumbricoides in the gastrointestinal and biliary tracts. Ultrasound Q 2009;25:207-9.

27. Das CJ, Kumar J, Debnath J, Chaudhry A. Imaging of ascariasis. Australas Radiol 2007;51:500-6.

28. Mahmood T, Quraishy S, Hussain S. Ultrasonographic appearance of Ascaris lumbricoides in the small bowel. J Ultrasound Med 2001;20:269-74.

29. Ajadi TA, Kiridi EK, Aremu AA, Kiridi EG. Sonographic diagnosis of Ascariasis lumbricoides presenting as a case of massive abdominal swelling: A case study. Int J Sci Res 2018;7:826-8.

30. Gowon AI, Baba OV, Baba OI, Akpu PA, Lynda AE. Ascaris lumbricoides infection using microscopy and IgG4 detection techniques in a school children population in central Nigeria: An epidemiological study. J Infect Dis Treat 2018;4:1-5.

31. Balakumar K. Ultrasound diagnosis of intestinal ascariasis. Indian $\mathbf{J}$ Radiol Imag 2005; 15:107-8.

32. Raina AH, Yattoo GN, Wani FA, Para RA, Changa KH, Parry AH. Pancreatitis secondary to Ascaris lumbricoides: A case series analysis. Int J Med Res Health Sci 2013;2:673-7.

33. Montorfano M. Ascaris lumbricoides: Role of ultrasound in diagnosis and management of abdominal manifestation. J Ultrason Echogr Med 1998;19:394-8.

34. Hall A, Romanova T. Ascaris lumbricoides: Detecting its metabolites in the urine of infected people using gas-liquid chromatography. Exp Parasitol 1990;70:35-42.

35. Lamberton PH, Jourdan PM. Human ascariasis: Diagnostics update. Curr Trop Med Rep 2015;2:189-200.

36. Holland CV, Asaolu SO, Crompton DW, Stoddart RC, Macdonald R, Torimiro SE. The Epidemiology of Ascaris lumbricoides and Other Soil-Transmitted Helminths in Primary School Children from Ile-Ife, Nigeria. Nigeria: Cambridge University Press; 1989. p. 275-85.

37. Lejkina ES. Research on ascariasis immunity and immunodiagnosis. Bull World Health Organ 1965;32:699-708.

38. Santra A, Bhattacharya T, Chowdhury A, Ghosh A, Ghosh N,
Chatterjee BP, et al. Serodiagnosis of ascariasis with specific IgG4 antibody and its use in an epidemiological study. Trans R Soc Trop Med Hyg 2001;95:289-92.

39. Zaman S, Afshan K, Firasat S, Jahan S, Qayyum M. Measurement of Ascaris lumbricoides IgG antibody, associated risk factors and identification of serum biochemical parameters as biomarkers of pathogenicity: Among patients with gastrointestinal complains in Pakistan. Trop Biomed 2018;35:10-25.

40. Hotez PJ, Bundy DA, Beegle K, Brooker S, Drake L, de Silva NR, et al. Disease Control Priorities in Developing Countries. Washington: World Bank Group; 2006. p. 467-78.

41. Sugianto R, Sukarno V, Sudarmaja M, Swastika K. Water source as the main risk factor of soil-transmitted helminths infection on primary school students in Antiga Village, Bali. Asian J Pharm Clin Res 2019;12:119-21.

42. Khan W, Imran R, Wahab A. Intestinal obstruction by Ascaris lumbricoides in a 12-year-old boy: A case report in Pakistan. J Bacteriol Parasitol 2016;7:1.

43. World Health Organization. Helminth Control in School-Age Children: A Guide for Managers of Control Programmes. $2^{\text {nd }}$ ed. Geneva: World Health Organization; 2011

44. World Health Organization. Model Lists of Essential Medicines. $17^{\text {th }}$ ed. Geneva: World Health Organization; 2011.

45. World Health Organization. Preventive Chemotherapy in Human Helminthiasis. Geneva: World Health Organization; 2006. p. 74

46. O'lorcain P, Holland CV. The public health importance of Ascaris lumbricoides. Parasitology 2000;121:S51-71.

47. Hagel I, Giusti T. Ascaris lumbricoides: An overview of therapeutic targets. Infect Disord Drug Targets 2010;10:349-67.

48. Li D, Sun L, Wu D, Jand S. Treatment of 119 cases with biliary ascariasis with the decoction of Artemisia capillaries and Coptis chinensis. J Tradit Chin Med 1991;22:9-10.

49. Lu, S. Observations on therapeutic effects on the treatment of 167 cases with biliary ascariasis with the complex decoction of Cotex miliae toosendan. Human J Tradit Chin Med 1992;12:127.

50. Xianmin Z, Weidong $P$, Crompton DW, Jaingqin X. Patterns of transmission, prevalence and intensity of soil-transmitted helminthiasis in Nsukka Zone, Enugu State, Nigeria. Trans R Soc Trop Med Hyg 1999;93:561-4.

51. Yi W. Treatment of 155 cases with biliary ascariasis with the decoction of Fructus mume. J Tradit Chin Med 1984;1:14. 